\title{
GROWTH AND YIELD OF Shorea parvifolia PLANTED UNDER AKASIA PLANTS IN KAPUAS, CENTRAL KALIMANTAN
}

\author{
Wahyudi \\ Department of Foresty, University of Palangka Raya \\ Jl. Yos. Sudarso Kampus Unpar, Palangka Raya, 70111 Central Kalimantan, Indonesia \\ Corresponding author: wahyudi888@yahoo.com \\ Mobile: 06281521560387 ,
}

\begin{abstract}
Shorea parvifolia is the native species of Kalimantan and has a high commercial value. This research was aimed to analysis the growth and yield of meranti planted under Acacia mangium stands, as enrichment planting on the TPTI silvicultural system. The research was conducted at Kapuas District, Central Kalimantan Province. Type of soil at the site is ultisol with $2606 \mathrm{~mm} /$ year of precipitation average. Initially, Acacia mangium planted with space namely $3 \times 3 \mathrm{~m}$ at 1993. After two years, seedlings of Shorea parvifolia were planted among akasia plants with 1111 tress/ha of density. Thinning of akasia plants were conducted stage by stage, especially at the stunted plants or dead. The data were latest analyzed at 2014 or at the moment of 20 years old. Research result showed that at the 1, 5, 10, 15, and 15 years old, life percentage of Shorea parvifolia are $94.8 \%, 78 \%, 66.4 \%, 57.5 \%$, and 53\% respectively. Average diameter of Shorea parvifolia at the same times are $1.27 \mathrm{~cm}, 6.13 \mathrm{~cm}, 12.8 \mathrm{~cm}, 19.86$, and $27.46 \mathrm{~cm}$ respectively, and their average total height are $1.51 \mathrm{~m}, 5.27 \mathrm{~m}, 10.89 \mathrm{~m}, 17.18 \mathrm{~m}$, and $24.41 \mathrm{~m}$ respectively. Volume growth of Shorea parvifolia at the same times namely $0.05 \mathrm{~m}^{3} / \mathrm{ha}, 3.97 \mathrm{~m}^{3} / \mathrm{ha}, 36.93 \mathrm{~m}^{3} / \mathrm{ha}, 145.44 \mathrm{~m}^{3} / \mathrm{ha}$, and $303.62 \mathrm{~m}^{3} /$ ha respectively.
\end{abstract}

Key words: growth and yield, CAI, MAI, Shorea parvifolia.

\section{INTRODUCTION}

Logs production from natural production forest tended decreasing, start from 26 million $\mathrm{m}^{3}$ coming from 59,6 million ha of production forest in 90s become become just 9.1 million $\mathrm{m}^{3}$ from 27,8 million ha of production forest only in 2000 (APHI 2014). Deforestation and degraded forest won't be stoped happened if there isn't repair of production forest management system in Indonesia. This research was aimed to analyze growth and yield of Shorea spp that planted under plantation of Acacia mangium at the dryland tropical forest in Central Kalimantan Province, Indonesia.

\section{METHOD}

The research was executed at the research plot of Shorea parvifolia that planted at 1995 under Acacia mangium plantation that planted at 1993, located at the dryland tropical forest, Kapuas District, Central Kalimantan Province, Indonesia. Type of soil is ultisol with $2606 \mathrm{~mm} / \mathrm{year}$ of precipitation average. Initially, Acacia mangium planted with space namely $3 \mathrm{~m} \times 3 \mathrm{~m}$. After two years, seedlings of meranti were planted among akasia plants with 1111 tress/ha of density. Thinning of Acacia mangium plants were conducted stage by stage, especially at the stunted plants or dead. The data of Shorea parvifolia were latest analyzed at 2014 or at the moment of 20 years old.

Table 1. Growth of Shorea parvifolia at the research plots

\begin{tabular}{cccccc}
\hline Year & $\begin{array}{c}\text { Age } \\
(\text { year })\end{array}$ & $\begin{array}{c}\text { Diameter } \\
(\mathrm{cm})\end{array}$ & $\begin{array}{c}\text { Height of branch } \\
(\mathrm{m})\end{array}$ & $\begin{array}{c}\text { Total height } \\
(\mathrm{m})\end{array}$ & $\begin{array}{c}\text { Life Perc. } \\
(\%)\end{array}$ \\
\hline 1995 & 1 & 1.27 & 0.55 & 1.52 & 94.8 \\
1999 & 5 & 6.13 & 2.22 & 5.27 & 78.0 \\
2004 & 10 & 12.8 & 5.56 & 10.89 & 66.4 \\
2009 & 15 & 19.86 & 10.5 & 17.18 & 57.5 \\
2014 & 20 & 27.46 & 12.44 & 24.41 & 53.0 \\
\hline
\end{tabular}

Source: worked data 
Table 2. Annual growth of volume of Shorea parvifolia

\begin{tabular}{ccccc}
\hline Year & $\begin{array}{c}\text { Age } \\
\text { (year) }\end{array}$ & $\begin{array}{c}\text { Standing } \\
\text { stock }\left(\mathrm{m}^{3} / \mathrm{ha}\right)\end{array}$ & $\begin{array}{c}\text { MAI Vol } \\
\left(\mathrm{m}^{3} / \text { ha/year }\right)\end{array}$ & $\begin{array}{c}\text { CAI Vol } \\
\left(\mathrm{m}^{3} / \text { ha/ } / \text { year }\right)\end{array}$ \\
\hline 1995 & 1 & 0.05 & 0.05 & 0.05 \\
1999 & 5 & 3.97 & 0.79 & 1.45 \\
2004 & 10 & 36.93 & 3.69 & 11.12 \\
2009 & 15 & 145.44 & 9.70 & 15.30 \\
2014 & 20 & 303.62 & 15.18 & 42.88 \\
\hline
\end{tabular}

Source: worked data

Measured variables were diameter breast high (dbh) and height of Shorea parvifolia that planted under Acacia mangium stands. Collection of data were conducted at $1,5,10,15$, and 20 years old, then analyzed using life percentage, mean annual increment, and current annual increment.

\section{RESULT AND DISCUSSION}

\section{Growth of Shorea leprosula}

Iniatially (at the 1995) the density of Shorea parvifolia plantation is 1111 tree per ha. However after 20 years later the density get down to 589 trees per ha.

\section{Yield of Shorea parvifolia}

At the 20 years old Shorea parvifolia has mean productivity namely $15.18 \mathrm{~m}^{3} /$ ha/year whereas at the same time, current productivity of Shorea parvifolia is highest than mean productivity, namely $42.88 \mathrm{~m}^{3} /$ ha/year, it show that plants still in the range of high growth. At the moment, standing stock of Shorea parvifolia stand attain $303.62 \mathrm{~m}^{3} / \mathrm{ha}$.

\section{CONCLUSION}

Shorea parvifolia is the native species of Kalimantan and it suitable grow at the site. Life percentage of Shorea parvifolia at the $1,5,10,15$, and 15 years old namely $94.8 \%, 78 \%, 66.4 \%, 57.5 \%$, and $53 \%$ respectively. Average diameter of Shorea parvifolia at the same times namely $1.27 \mathrm{~cm}, 6.13 \mathrm{~cm}, 12.8 \mathrm{~cm}$, 19.86 , and $27.46 \mathrm{~cm}$ respectively, and their average total height are $1.51 \mathrm{~m}, 5.27 \mathrm{~m}, 10.89 \mathrm{~m}, 17.18 \mathrm{~m}$, and 24.41 $\mathrm{m}$ respectively. Volume growth of Shorea parvifolia at the same times namely $0.05 \mathrm{~m}^{3} / \mathrm{ha}, 3.97 \mathrm{~m}^{3} / \mathrm{ha}, 36.93$ $\mathrm{m}^{3} / \mathrm{ha}, 145.44 \mathrm{~m}^{3} / \mathrm{ha}$, and $303.62 \mathrm{~m}^{3} /$ ha respectively.

\section{REFERENCE}

APHI. 2014. Produktivitas Hutan Alam Produksi dan Tantangan Ke Depan. Asosiasi Pengusaha Hutan Indonesia, Jakarta. 